\title{
Investigating the Effects of Government Expenditure and Money Supply on Unemployment in Namibia
}

\author{
Wilhelmine Naapopye Shigwedha ${ }^{1}$, Teresia Kaulihowa ${ }^{2}$ \\ ${ }^{1}$ University of Namibia, Windhoek, Namibia \\ ${ }^{2}$ Namibia University of Science \& Technology, Windhoek, Namibia \\ kaulihowat@gmail.com,wshigwedha@gmail.com
}

\begin{abstract}
This paper examines how government expenditure and money supply affect unemployment in Namibia. It employs the ARDL and ECM estimation techniques to establish the underlying relationship for the period 1980-2018. The results support the hypothesis that government expenditure and money supply can be used to contain unemployment. Additionally, an evidence of both long and short-run causality from government expenditure and money supply to unemployment is found. Practical policy implications indicate that in order to effectively combat unemployment problem in Namibia, the study recommends that there is a need for policy makers to ensure that the goal of employment creation is mainstreamed in all relevant fiscal and monetary policies responses in the country. Moreover, there is also a need to identify and propose policies that can help to do away with the lack of effective policy interventions.
\end{abstract}

Keywords: Namibia, Unemployment, Government Expenditure, Money Supply and Cointegration.

\section{Introduction}

Economists still argue on the basic dilemma, whether expansionary government expenditure or money supply can enhance economic growth that translates into a low level of unemployment (Attamah, Anthony \& Ukpere, 2015). A fiscal/monetary expansion in terms of government spending/money supply is presumed to play a role in the mitigation of unemployment as well as stabilising the economy. Countries that are facing downturns pursue a range of fiscal strategies such as expenditure on public work projects and tax cuts in order to stabilise their economies. The hypothesis that fiscal expansion would enhance employment creations is logical when it comes to economic literature and might have worked for many economies. However, an expansionary fiscal policy that is exclusive to employment creation could be redundant because policy makers' willingness to use fiscal policy to reduce unemployment is tempered by a high level of debt. Poorly targeted fiscal instrument may worsen deficit financing that is unresponsive to unemployment. On the other hand, if the tax incentives are used to enhance the investment climate and thereby increase employment. In this way, it would result in a better targeted fiscal response to address policy issues. However, Government expenditure alone may not be enough to curve unemployment especially in a case such as that of Namibia where unemployment is 33.4 per cent (Namibia Statistics Agency, 2018). Additionally, emerging countries use monetary policy variables in terms of money supply to target employment. The basis is that when interest is low, companies would borrow money to expand which then leads to job creation.

Empirical literature that addresses the effect of government expenditure and money supply on unemployment is very scanty in Africa. Attamah, Anthony and Ukpere (2015); Sunde (2015); Sunde \& Akanbi, 2016 are among the few that examined how fiscal and/or monetary policy affects unemployment in African economies. Attamah, Anthony and Ukpere (2015) found supporting evidence that both fiscal and monetary policy exhibits positive effects on unemployment in Nigeria. This finding is consistent in both the short and long-run. Contrary to Attamah, Anthony and Ukpere (2015) findings, Sunde (2015) examined the effects on monetary policy on unemployment in Namibia and established that the monetary policy has an influence on unemployment only in the short-run but, ineffective in the long-run leading to mixed views in the literature. The recent rising trends of the unemployment rate in Namibia called for concern among policymakers (Sunde \& Akanbi, 2016). Despite the huge government expenditure on sectors such as education, health, agricultural and infrastructure development, there has been a persistent decreasing level of employment in the country. In addition, the positive annual growth of broad money supply continued to be experienced with $9.5 \%$ and $4.9 \%$ for the periods 2017 and 2016 respectively (Bank of Namibia, 2017). In light of the above, the relevant question arising from such a scenario is to what extent fiscal and/or monetary expansion affects the rate of unemployment in Namibia? 


\section{Trend Analysis of Government Expenditure, Money Supply \& Unemployment}

Overview of Unemployment in Namibia: Unemployment in Namibia is defined based on international statistical standards. This view renders the classical predictions unrealistic. Hence, unlike the Classicalists, the Keynesians recommend fiscal policy measures in reducing unemployment (Wickens, 2008). By using strict definition, it is defined as, being without work, being available for work and actively seeking work. However, in the broader sense, unemployment is defined as "all persons within the economically active population or working age group who meet the following two criteria, irrespective of whether or not they are actively seeking work: being without work and being available for work" (Namibia Statistics Agency, 2016). Figure 1 below shows the trend in annual unemployment rates in Namibia. An upward trend was depicted in the unemployment rate over the period under review. The Namibian unemployment rate displayed modest fluctuations around an average level of 19 per cent during the 1980s and 1990s.

The 2008 global financial crisis and economic challenges such as drought which the country experienced in 2013 entailed higher unemployment rates than what was observed for the periods 1980s - 1990s. The effects of the global economic crisis triggered an increase in unemployment resulting from either closure of companies, downsizing and workers' retrenchments especially in the mining and fishing industries as a result of a decrease in international demand for the respective commodities (Mwinga, 2012). The unemployment rate in Namibia remains high. In 2018, Namibia reported an overall unemployment rate of 33.4\%. In addition to this females recorded the highest unemployment rate of 34.3 per cent compared to their male counterparts who recorded a 32.5 per cent. Moreover, those who live in rural areas are more unemployment when compared to their urban counterparts with $33.5 \%$ and 33.4\%, respectively (Namibia Statistics Agency, 2018).

\section{Figure 1: Annual Unemployment Rate}

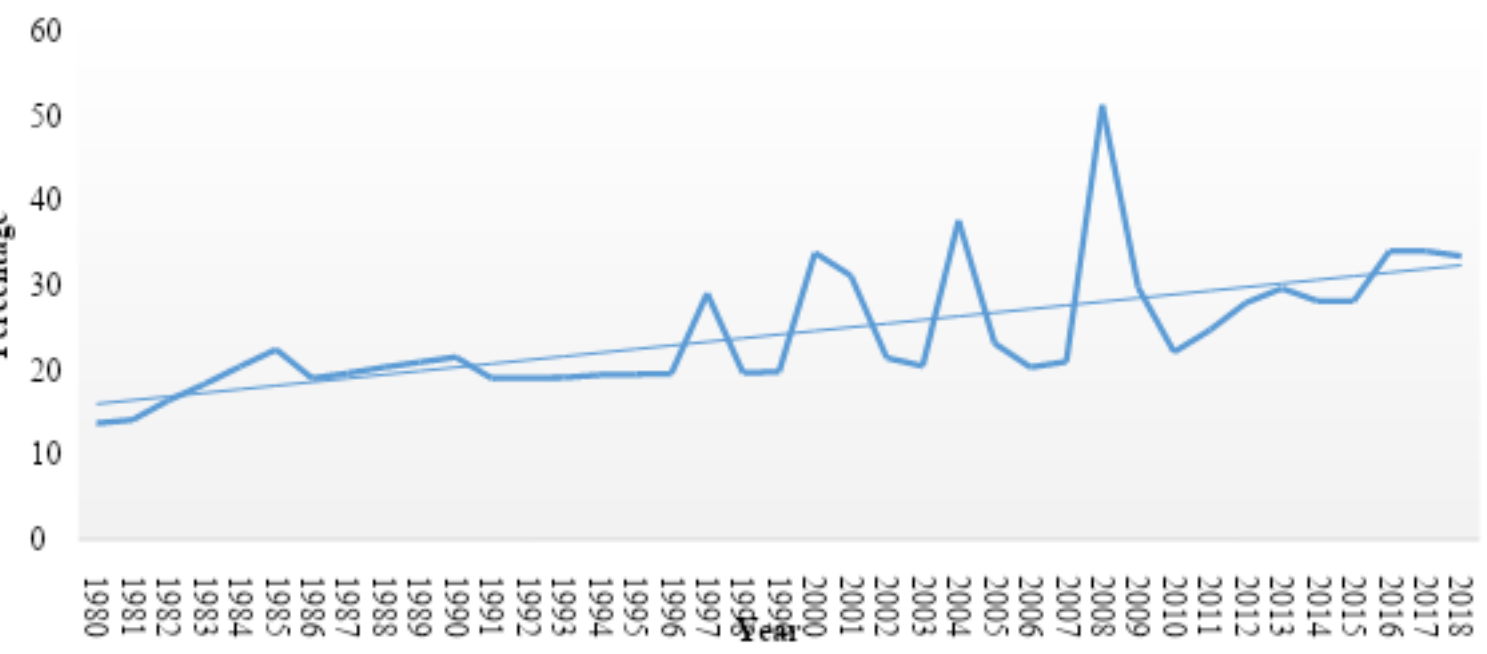

Source: Author's compilation

Overview of Government Expenditure in Namibia: The government expenditure in Namibia comprises two components namely, operational and developmental expenditure. Operational expenditure makes up over 80 per cent of the total budget with more than a third of that amount allocated to personal related expenditure. Development expenditure, on the other hand, favours the priority areas of the National Development Plan (NDP) of which about a third of the total capital expenditure is allocated to these sectors (Nakale, Sikanda, \& Mabuku, 2015). Hayek believes that the use of monetary policy can be effective in times of extensive unemployment of all kinds throughout the economy. Since independence, Namibia has recorded a high growth in total expenditure with the 2000/01 financial year recording a 35 per cent total expenditure as a share of Gross Domestic Product (GDP). The share of total government expenditure to GDP increased from 34 per cent in the 2011/12 financial year to 40 per cent in the 2015/16 financial year. This increment was attributed to the demand-side oriented and counter cyclical fiscal measures (Bank of Namibia, 1991, 2001, 2011, 2017). Conversely, the country's labour market was stagnant and unresponsive to economic growth 
that they have experienced in recent years. The result was that fiscal policy became ineffective in enhancing the economy's production capacity to create employment opportunities thereby reducing unemployment.

Figure 2: Total Expenditure as a Ratio of GDP

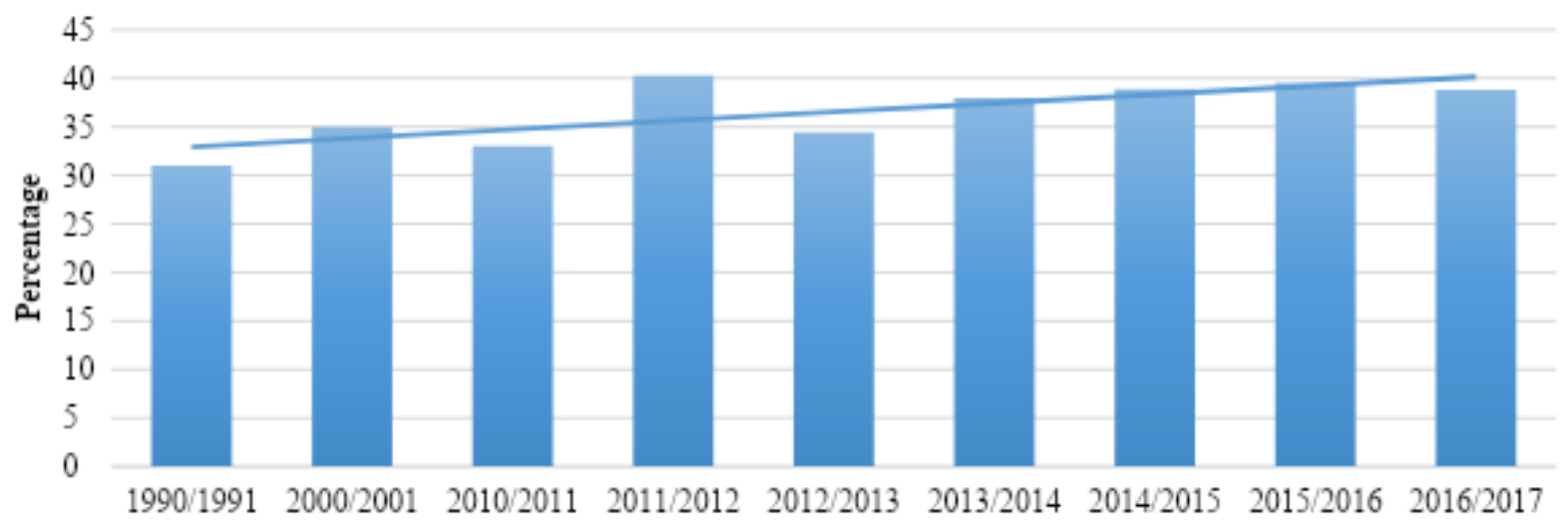

Source: Author's compilation

Overview of Broad Money Supply (M2) in Namibia: In the Namibian context, broad money supply (M2) comprises of narrow money plus other deposits. Other deposits translate as the "sum of currency outside depository corporations, transferable and other deposits in national currency of the resident sectors, excluding deposits of the central government and those of the depository corporations" (Bank of Namibia, 2017). Figure 3 depicts the evolution of broad money supply in Namibia from 1980 to 2018. It shows a downward trend, with higher spikes in 1988 and 2006 of above 25 A high growth of 25.2 per cent that was recorded in 2006 has from net foreign assets as the growth of domestic credit slowed. The lowest growth of 4.9 per cent in broad money supply recorded in 2016 was mainly attributed to a fall in net foreign assets and a weaker credit extension to the private sector (Bank of Namibia, 2016).

Figure 3: Annual Growth Rate in Broad Money Supply

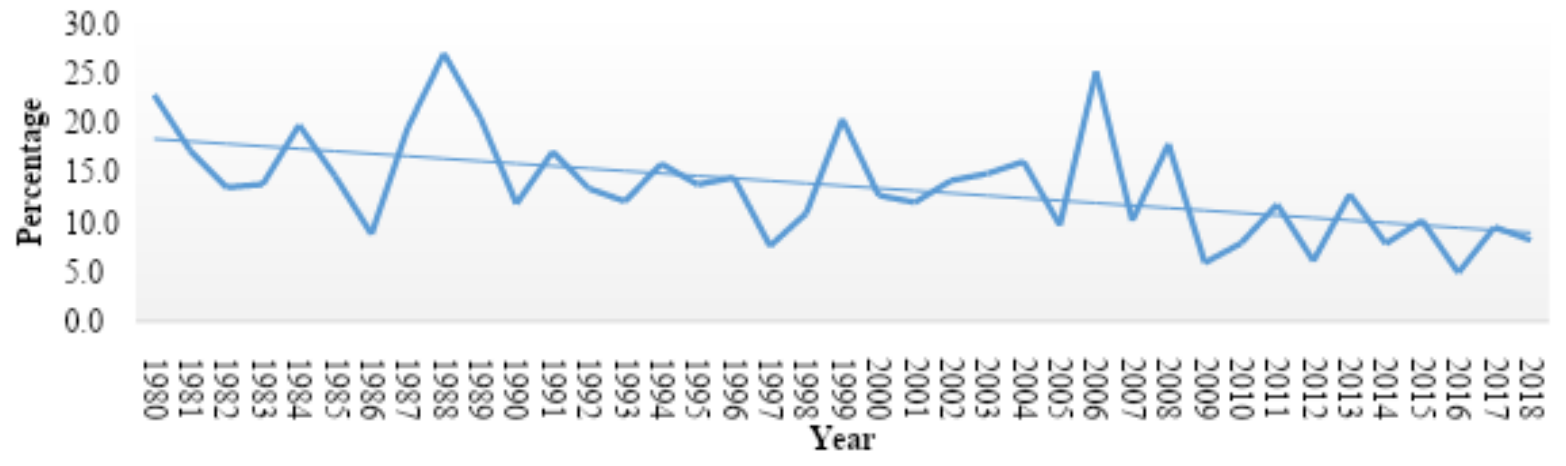

Source: Author's compilation

\section{Literature Review}

Theoretical Literature: The concept of unemployment is perceived differently among economists. The classical economist's argument on the concept of unemployment is based on the Walrasian General Equilibrium Model (Sodipo \& Ogunrinola, 2011). The Classicalist assumes full employment of labour. Moreover, they assumes that prices and wages are highly flexible which makes the economy to converge to full employment when there are disequilibrium's in the labour market (Humphrey, 1974). In the classicalist view, the general unemployment is impossible given that labour and other resources are always fully employed. However, in the event where any unemployment is experienced, it is assumed to be temporary. This indicated the market forces will always corrects itself toward equilibrium. Based on the above 
assumption the classicalist believes that unemployment is caused by government intervention, wrong calculations and inaccurate decisions by entrepreneurs as well as artificial resistance (Sodipo \& Ogunrinola, 2011). The Keynesian economists, on the other hand, do not assume full employment of labour. They argue that the equilibrium can be realised at a level of output below full employment and at that level, part of the labour force remains unemployed. Keynesians believe that increasing the aggregate demand will restore full employment and not reduce the money wage as espoused by the classical views. The Keynesians premised their argument on the assumption that wages are flexible such that workers through their union could resist wage cuts.

The Hayek economists however, argue that targeting expansionary fiscal policy instruments to reduce unemployment may results in inflation such that monetary authority would have to increase money supply in order to keep the level of unemployment low (Sanz-Bas, 2011). Even though Hayek believed that there was a connection between expansionary monetary policies towards upholding full employment, he viewed the connection as indirect thereby not finding the conduct of monetary policy with central planning as such (Arevuo, 2012). Unlike the Keynesians, the monetarists believe that monetary policy is the most powerful instrument to stabilise the economy and has an influence on economic activity than fiscal policy (Dwivedi, 2005). They argue that the use of fiscal policy may trigger impermanent rise in output such that in the long run, an increase in government expenditure will only cause inflation and may not necessarily change the output. The monetarists are of the view that supply side policies are more effective to address unemployment when compared to demand side policies.

Empirical Literature: Among the reviewed empirical literature, Eita and Ashipala (2010) studied the determinants of unemployment between 1971 and 2007 in Namibia. Their study supports the hypothesis that national output and wages positively impact unemployment while inflation negatively affects unemployment. In a similar study, Sunde and Akanbi (2016) used the structural vector autoregressive (SVAR) method and cover the period 1980 to 2013. They found a combination of various shocks and hysteresis mechanism to be the cause of the persistently high unemployment in Namibia. In addition, it was established that labour supply, real wages and aggregate demand impact unemployment in the country. Furthermore, price shocks were found to be effective in the long-run whereas productivity was effective in the short as well as the longrun. Alexius and Holmlund (2007) analysed the effect of monetary policy on unemployment in Sweden by employing the SVAR model. Their findings revealed that 22 and 30 per cent of variations in Sweden unemployment are explained by monetary policy shocks. This indicates that there supporting evidence that monetary policy has significant influence on unemployment. It is important to note that their study only concentrated on one monetary policy variable, the real interest rate channel.

In the same line, Tagkalakis (2013) studied the effects of fiscal policy on unemployment in Greece. It was found that unemployment and growth was responsive to a decrease in government spending, consumption and investment. Furthermore an inverse relationship between taxes and unemployment as well as growth was found. The effectiveness of fiscal policy to stimulate output and unemployment was found to be more significant when considering recent year developments in the country. This is when compared to the precrisis years. In Namibia, Sunde (2015) explored how monetary policy affects unemployment over the period 1980 to 2013 by employing SVAR. The study used exchange and bank lending rates channels. There is supporting evidence that monetary policy is only effective in the short-run but ineffective in the long-run. On the contrary, other studies (Alexius and Holmlund, 2007); Jacobs, Kuper and Sterken, 2003) have supported both the short and the long-run hypothesis. As such, the inclusion of money supply and fiscal policy measures in this study will contribute to ambiguities in the existing literature.

In line with the above views, Attamah, Anthony and Ukpere (2015) used both fiscal and monetary policies variables to examine their effect on unemployment in Nigeria. They found that government expenditure, money supply and exchange rate exhibit a positive effect on unemployment. The findings are consisted with Etale and Ujuju (2016) who did the same study in Nigeria. This is with exception of the exchange rate channel, where an inverse relationship was reported. Sebuliba (2017) did a similar study for Uganda, using various estimation techniques. The use of the Fully Modified Least Squares (FMOLS) in the study found a negative relationship between total government expenditure and unemployment. However, the results of the Dynamic Least Squares (DOLS) found the relationship between fiscal variables and unemployment to be insignificant. 
With regards to monetary policy, the results revealed that both interest rate and exchange rate have a negative effect on unemployment. On a broader view, Onodugo et al. (2017) used capital and recurrent expenditure to explore how the public sector expenditure affects unemployment in an emerging market. There is supporting evidence that capital expenditure has a positive effect on unemployment in medium to long-run while there reverse is true for the recurrent expenditure. Similar c results were also obtained by Nwosa (2014).

\section{Methodology}

The paper employs a quantitative research strategy to examine how fiscal and/or monetary policy can be used to address Namibia developmental agenda of employment creations. In this paper, an Autoregressive Distributed Lag (ARDL) model that was introduced by Pesaran, Shin and Smith (2001) is used examine the underlying objectives. The ARDL model is considered to be efficient in estimations that involve small sample size. The authors acknowledges lack of data in Namibia for the period before 1980 hence, the available small samples of data were used making the use of ARDL model to be appropriate. Moreover, the model allows testing for the existence of a relationship between variables in levels using a combination of variables I (1) and I ( 0 ) as regressors which is also the case in this study.

Econometric Framework and Modelling Specification: For purposes of estimating the econometric model, the study complied with the following steps: Unit roots test, bound test for cointegration, estimation of error correction model, diagnostic tests and Granger causality test. The presence of a unit root was determined using the Augmented Dickey-Fuller (ADF) and Phillips-Perrons (PP) tests. The general ADF expression is given by;

$X_{t}=\alpha_{t}+\beta_{t} t+\rho X_{t-1}+\sum \delta \Delta X_{t-1}+\mu_{t}$

Where: $X_{t}$ denotes a time series variable, $\mathrm{t}$ represent the time $\mathrm{t}$ and $\mu_{t}$ denote a stochastic error term normally. The PP test on the other hand, includes fitting the regression. The PP test equation is as follows:

$Y_{t}=Z_{1}+\lambda y_{t-1}+Z_{2}\left(t-\frac{T}{2}\right)+\sum_{i=0}^{n} \quad \delta_{i} \Delta Y_{t-1}+\mu 2_{t}$

Where: $Y_{t}$ is the time series variable, $\mathrm{T}$ is the estimated sample size and $\mu 2_{t}$ denotes the covariance stationary disturbance error term Unit root test hypothesis are;

$H_{0}: \rho=0$ (unit root)

$H_{1}: \rho \neq 0$ (no unit root)

The null hypothesis is rejected when the test statistics is less than the critical value with a significant aspects of 5 per cent thereby confirming the stationary alternative hypothesis (Byrne \& Perman, 2007).

Thereafter, an ARDL equation is constructed in order to perform the bound $\mathrm{F}$ test in probing the existence of a cointegration property.

$\Delta U_{t}=\alpha_{0}+\sum_{i=1}^{p} \quad \alpha_{1 i} \Delta U_{t-i}+\sum_{i=1}^{q 1} \quad \alpha_{2 i} \Delta G E_{t-i}+\sum_{i=1}^{q 2} \quad \alpha_{3 i} \Delta M 2_{t-i}+\sum_{i=1}^{q 3} \quad \alpha_{4 i} \Delta I_{t-i}+\beta_{1} U_{t-1}+$ $\beta_{2} G E_{t-1}+\beta_{3} \Delta M 2_{t-1}+\beta_{4} I_{t-1}+\varepsilon_{t}$

Where: $\alpha_{0}$ denote the intercept term and the first difference operator is denoted by $\Delta$. In equation 3 the order ( $\mathrm{p}, q_{1}, q_{2}, q_{3}$ ) represents lags as determined by various information criteria. These include; the Akaike's Information Criteria (AIC), Hannan-Quinn (HQ), Schwarz Information Criterion (SC), Final Prediction error (FPE) and Likelihood Ratio (LR). In order to test the cointegration property the computed F-statistic value is assessed against the critical values. This applies to both lower and upper bounds. When computed F-statistic falls below the lower bound, it's an indication that there is no co-integration. Similarly, the cointegration property is rejected when computed F-statistic exceeds the upper bound. Whereas inconclusive is said to occur when computed F-statistic falls between the lower and upper bounds. When the cointegration property is not supported, a short-run version of the ARDL (p, $q_{1}, q_{2}, q_{3}$ ) will be specified as:

$\Delta U_{t}=\beta_{0}+\sum_{i=1}^{p} \quad \alpha_{1 i} \Delta U_{t-i}+\sum_{i=1}^{q_{1}} \quad \alpha_{2 i} \Delta G E_{t-i}+\sum_{i=1}^{q_{2}} \quad \alpha_{3 i} \Delta M 2_{t-i}+\sum_{i=1}^{q_{3}} \quad \alpha_{4 i} \Delta I_{t-i}+\varepsilon_{t}$ 
However, when the cointegration property is supported, an error corrected version will be is specified. The Error Correction Model (ECM) encompasses both short and long -run dynamics. It captures the degree at which at which short-run shocks are corrected to equilibrium (Dağdeviren \& Sohrabji, 2012). The specification of the ECM is expressed as;

$$
\Delta U_{t}=\beta_{0}+\sum_{i=1}^{p} \quad \alpha_{1 i} \Delta U_{t-i}+\sum_{i=1}^{q_{1}} \quad \alpha_{2 i} \Delta G E_{t-i}+\sum_{i=1}^{q_{2}} \quad \alpha_{3 i} \Delta M 2_{t-i}++\sum_{i=1}^{q_{3}} \quad \alpha_{4 i} \Delta I_{t-i}+\lambda_{1} E C T_{t-1}+\varepsilon_{t}
$$

Where: $\lambda$ represent rate at which variable/s corrects to equilibrium while error correction term (ECT) is a stochastic residual term. The coefficient of the error correction term $(\lambda)$ has to be negative which is an indication of convergence to equilibrium and also suggests cointegration relation. A divergence from equilibrium will occur when 0 is positive coefficient of the ECT indicates a divergence from the equilibrium.

In addition, the ECM provides the opportunity to decompose the long and short-run causality issues.

The causality hypotheses are as follows:

$H_{01}$ : Unemployment does not Granger cause Government Expenditure

$H_{11}$ : Unemployment Granger causes Government Expenditure

$H_{02}$ : Unemployment does not Granger causes Money Supply

$H_{12}$ : Unemployment Granger causes Money Supply

$H_{03}$ : Government expenditure does not Granger causes unemployment

$H_{13}$ : Government expenditure Granger causes unemployment

$H_{04}$ : Money Supply does not Granger cause unemployment

$H_{14}$ : Money Supply Granger causes unemployment

Lastly, the diagnostic check was done by testing for robustness through employing various diagnostics tests of the residuals. The diagnostic tests that were performed include the: Breush-Godfrey, Breusch-PaganGodfrey test for autocorrelation and heteroskedasticity respectively. These results imply that the direction of causality from government expenditure and money supply. Additionally the Jargue-Bera and Ramsey RESET tests are used to examine the normality and the stability of the model. The a-priori expectations of the regressors are summarised in Table 1 below.

Table 1: Summary of the Expectations Signs

\begin{tabular}{|c|c|c|}
\hline Variables & $\begin{array}{l}\text { Expected } \\
\text { Signs/Relationship }\end{array}$ & Rationale \\
\hline $\begin{array}{l}\text { Government } \\
\text { Expenditure } \\
\text { (GE) }\end{array}$ & Negative(-) & $\begin{array}{l}\text { A negative relation is expected between Government spending } \\
\text { and unemployment as s rise in public spending further increases } \\
\text { aggregate demand which in turn leads to job creation thereby } \\
\text { reducing unemployment levels. Hence, an inverse relationship } \\
\text { between government expenditure and unemployment is } \\
\text { expected. This explanation is consistent with the Keynesian } \\
\text { theory of aggregate demand, which assumes that employment } \\
\text { creation is derived from total aggregate demand (Schiller, 2006). }\end{array}$ \\
\hline $\begin{array}{l}\text { Money Supply } \\
\text { (M2) }\end{array}$ & Negative(-) & $\begin{array}{l}\text { Money supply is expected to exhibit an inverse relationship with } \\
\text { unemployment. This is to the reasoning that an expansion in } \\
\text { money supply is likely to reduce unemployment as a result of low } \\
\text { interest rates and increased domestic investments (Mankiw \& } \\
\text { Taylor, 2007). }\end{array}$ \\
\hline $\begin{array}{l}\text { Inflation rate } \\
\text { (I) }\end{array}$ & Negative(-) & $\begin{array}{l}\text { According to the Phillips curve, inflation increases employment. } \\
\text { Therefore, the reverse is true for unemployment (Jelilov, Obasa \& } \\
\text { Isik, 2016). }\end{array}$ \\
\hline
\end{tabular}

Source: Author's compilation

\section{Empirical Results and Discussion}

Unit Root Test: Prior to regression analysis, the paper examined the unit root property using the tests explained in the methodology section. The results are presented in Table 2. Both ADF and PP tests show that 


\section{Journal of Economics and Behavioral Studies (ISSN: 2220-6140)}

Vol. 12, No. 4, pp. 73-83, August 2020

there is a mixture various order of integration. Some variables are integrated of order zero (I (0)) while inflation is integrated of and order one (I (1)). This underscores the relevance of the ARDL approach to examine the cointegration property.

Table 2: Stationarity Test Results

\begin{tabular}{|c|c|c|c|c|c|c|}
\hline Variable & $\begin{array}{l}\text { Model } \\
\text { Specification }\end{array}$ & $\begin{array}{l}\text { ADF } \\
\text { Levels }\end{array}$ & $1^{\text {st }}$ Diff. & $\begin{array}{l}\text { PP } \\
\text { Levels }\end{array}$ & $1^{\text {st }}$ Diff. & $\begin{array}{lr}\text { Order } & \text { Of } \\
\text { Integration }\end{array}$ \\
\hline \multirow[t]{3}{*}{$\mathbf{U}$} & Constant & -0.6188 & $-9.3925^{*}$ & $-3.3205^{*}$ & $-16.331^{*}$ & \multirow{3}{*}{$\mathrm{I}(0)$} \\
\hline & Constant and Trend & $-7.1237^{*}$ & $-9.2431 *$ & $-11.938^{*}$ & $-15.945^{*}$ & \\
\hline & None & 1.9825 & $-8.6759 *$ & 0.5961 & $-12.069 *$ & \\
\hline \multirow[t]{3}{*}{ GE } & Constant & $-5.2332^{*}$ & $-7.7290^{*}$ & $-5.0947 *$ & $-8.5514^{*}$ & \multirow[t]{3}{*}{$\mathrm{I}(0)$} \\
\hline & Constant and Trend & $-4.7967 * *$ & $-7.6096^{*}$ & $-4.7199 *$ & $-8.3572 *$ & \\
\hline & None & 0.4546 & $-7.8534^{*}$ & 0.5173 & $-8.6799 *$ & \\
\hline \multirow[t]{3}{*}{ M2 } & Constant & $-3.1792^{* *}$ & $-10.476^{*}$ & $-5.1425^{*}$ & $-27.116^{*}$ & \multirow[t]{3}{*}{$\mathrm{I}(0)$} \\
\hline & Constant and Trend & $-6.5448^{*}$ & $-10.321^{*}$ & $-6.5723^{*}$ & $-26.319 *$ & \\
\hline & None & -1.2339 & $-10.585^{*}$ & $-1.6295^{* * *}$ & $-21.018^{*}$ & \\
\hline \multirow[t]{3}{*}{ I } & Constant & -2.3466 & $-8.0823^{*}$ & -2.0808 & $-14.403^{*}$ & \multirow{3}{*}{$\mathrm{I}(1)$} \\
\hline & Constant and Trend & $-4.7072^{*}$ & $-7.9685^{*}$ & $-4.7008^{*}$ & $-14.226^{*}$ & \\
\hline & None & -1.3809 & $-8.1008^{*}$ & -1.2501 & $-10.779 *$ & \\
\hline
\end{tabular}

Source: Author's compilation, Note that ${ }^{*},{ }^{* *}{ }^{* * *}$ indicate significance at 1,5 and $10 \%$, respectively.

Cointegration Test: The bound test for cointegration results is presented in Table 3 . It confirms the existence of the cointegration property, an indication that long-run relationship among the variables exist. Eita and Ashipala (2010); Sunde and Akanbi (2016) has similar findings. Given the above results, an ECM is therefore estimated.

Table 3: Bound Test Results

\begin{tabular}{llllll}
\hline $\begin{array}{l}\text { Dependent } \\
\text { Variable }\end{array}$ & F-Statistics & K & \multicolumn{2}{c}{ Significance } & \multicolumn{2}{c}{ Bound Critical Values } \\
L & & & Level & I(0) & I(1) \\
\hline $\mathbf{U}$ & 5.932270 & 3 & $10 \%$ & 2.72 & 3.77 \\
& & & $5 \%$ & 3.23 & 4.35 \\
& & $1 \%$ & 4.29 & 5.61 \\
\hline
\end{tabular}

Source: Author's compilation

ARDL Model Results: Long-Run: The long-run estimates are presented in Table 3. The findings are consistent with theoretical expectations in terms of signs, they are however insignificant with exception of inflation. This result is consistent Sunde (2015) who found monetary policy in Namibia to not have an effect on unemployment in the long run. Inflation was hypothesis was also supported by Sunde (2015).

Table 4: Long-Run Coefficient Results Dependent Variable U

ARDL(1,1,0,1)

\begin{tabular}{lllll}
\hline Variables & Coefficient & Std. Error & t-Statistic & Prob. \\
\hline GE & -0.0232 & 0.5345 & -0.0435 & 0.9656 \\
M2 & -0.3666 & 0.2024 & -1.8116 & 0.0797 \\
I & -0.6740 & 0.2885 & -2.3360 & 0.0261 \\
C & 36.1244 & 13.5843 & 2.6592 & 0.0123 \\
\hline
\end{tabular}


ECM Results: The error correction estimates in Table 5 indicates that there exists an inverse relationship between government expenditure and money supply. This implies that fiscal or monetary policy instruments can be used stimulate the much needed employment in Namibia. Similar results were also found by Tagkalakis (2013) and Sebuliba (2017). An expansionary fiscal policy (increase in government expenditure) further increases aggregate demand which in turn leads to job creation thereby reducing unemployment levels. Hence, a negative link between government expenditure and unemployment. This explanation is based on the Keynesian theory of aggregate demand, which assumes that employment creation is derived from total aggregate demand (Schiller, 2006). Similarly, an expansionary monetary policy (an increase in money supply) makes borrowing cheaper and easier thereby allowing more economic activities to occur which then reduces unemployment (Mankiw \& Taylor, 2007). The error correction term $\left(E C T_{t-1}\right)$ captures the speed of adjustment at which unemployment converges to its equilibrium level. It shows that the speed of adjustment is relatively at -1.063 , implying over $100 \%$ convergence rate. In this, the Durbin-Watson statistic of 1.992430 implies that there is not autocorrelation.

Table 5: ECM Results

\begin{tabular}{|c|c|c|c|c|}
\hline \multicolumn{5}{|c|}{$\begin{array}{l}\text { Dependent Variable } \Delta \mathrm{U} \\
\text { ARDL }(1,1,0,1)\end{array}$} \\
\hline Variables & Coefficient & Std. Error & t-Statistic & Prob. \\
\hline $\mathrm{C}$ & 0.5861 & 0.7707 & 0.7604 & 0.4531 \\
\hline$\Delta \mathrm{U}(-1)$ & 0.1631 & 0.1736 & 0.9396 & 0.3551 \\
\hline$\Delta \mathrm{GE}$ & -1.8226 & 0.6122 & -2.9769 & 0.0058 \\
\hline$\Delta \mathrm{GE}(-1)$ & 0.1525 & 0.4837 & 0.3153 & 0.7548 \\
\hline$\Delta \mathrm{M} 2$ & -0.2739 & 0.1384 & -1.9789 & 0.0574 \\
\hline$\Delta \mathrm{I}$ & 0.0527 & 0.2920 & 0.1805 & 0.8580 \\
\hline$\Delta \mathrm{I}(-1)$ & 0.6936 & 0.3380 & 2.0517 & 0.0493 \\
\hline \multirow[t]{2}{*}{ ЕСТ(-1) } & -1.0632 & 0.2310 & -4.6024 & 0.0001 \\
\hline & 0.5966 & & & \\
\hline F-stat & 6.1272 & & & \\
\hline Prob(F-stat) & 0.0001 & & & \\
\hline Durbin-Watson & 1.9924 & & & \\
\hline
\end{tabular}

Source: Author's compilation

Data Sources and Measurements: To facilitate the analysis, the paper used time series annual data from 1980-2018. The selection of the period was due to availability of data. The data were obtained from the database of the Namibia Statistic Agency (NSA), Bank of Namibia (BoN), the database of Eita and Ashipala (2010), as well as that of Shifotoka (2015). However, when the cointegration property is supported, an error corrected version will be is specified. The Error Correction Model (ECM) encompasses both short and long run dynamics. It captures the degree at which at which short-run shocks are corrected to equilibrium (Dağdeviren \& Sohrabji, 2012). The dependent variable is measured as ratio of unemployed persons to the total labour force $(\mathrm{U})$. The regressors are government expenditure (ratio of total government expenditure to GDP (GE)), growth of broad money supply (M2) and inflation rate (I) as a control variable added to the model.

Granger Causality Test: The causality results in Table 6 shows an evidence of both short and long-run unidirectional causality from Government expenditure to unemployment as well as from money supply to unemployment. These results imply that the direction of causality from government expenditure and money supply to unemployment have an important role in reducing unemployment in Namibia. This essentially means that the policymakers have to strengthen the effective use of fiscal/monetary policies in combating the high rate of unemployment in Namibia. In addition to the above, a joint causality hypothesis is also supported. 


\begin{tabular}{l} 
Journal of Economics and Behavioral Studies (ISSN: 2220-6140) \\
Vol. 12, No. 4, pp. 73-83, August 2020 \\
\hline \hline
\end{tabular}

Table 6: Wald Test Results

\begin{tabular}{|c|c|c|c|c|c|c|}
\hline \multirow[t]{2}{*}{$\begin{array}{l}\text { Dependent } \\
\text { Variables }\end{array}$} & \multicolumn{4}{|c|}{$\begin{array}{l}\text { Short-Run Causality } \\
\text { F-Statistic(p-value) }\end{array}$} & \multirow{2}{*}{$\begin{array}{l}\text { Long-Run } \\
\text { Causality } \\
\text { t-statistic } \\
\text { (p- value) }\end{array}$} & \multirow{2}{*}{$\begin{array}{l}\text { Joint } \\
\text { Causality } \\
\text { F-statistic } \\
\text { (p- value) }\end{array}$} \\
\hline & $\mathrm{U}$ & GE & M2 & I & & \\
\hline U & - & $\begin{array}{l}4.5839 \\
(0.0186)^{* *}\end{array}$ & $\begin{array}{l}3.9162 \\
(0.0574)^{* * *}\end{array}$ & $\begin{array}{l}2.1724 \\
(0.1321)\end{array}$ & $\begin{array}{l}-4.6025 \\
(0.0001)^{* *}\end{array}$ & $\begin{array}{l}6.3028 \\
(0.0003)^{* *}\end{array}$ \\
\hline GE & $\begin{array}{l}1.2924 \\
(0.2643)\end{array}$ & - & $\begin{array}{l}6.6232 \\
(0.0151)^{* *}\end{array}$ & $\begin{array}{l}0.0033 \\
(0.9543)\end{array}$ & $\begin{array}{l}-2.5871 \\
(0.0146)^{* *}\end{array}$ & $\begin{array}{l}3.6032 \\
(0.0159)^{* *}\end{array}$ \\
\hline M2 & $\begin{array}{l}2.2004 \\
(0.1289)\end{array}$ & $\begin{array}{l}4.9973 \\
(0.0137)^{* *}\end{array}$ & - & $\begin{array}{l}1.1883 \\
(0.2846)\end{array}$ & $\begin{array}{l}-3.8857 \\
(0.0005)^{* *}\end{array}$ & $\begin{array}{l}6.5131 \\
(0.0002)^{* *}\end{array}$ \\
\hline I & $\begin{array}{l}0.0329 \\
(0.8573)\end{array}$ & $\begin{array}{l}0.1401 \\
(0.7109)\end{array}$ & $\begin{array}{l}0.2072 \\
(0.8140)\end{array}$ & - & $\begin{array}{l}-2.3978 \\
(0.0229)^{* *}\end{array}$ & $\begin{array}{l}1.9532 \\
(0.1148)\end{array}$ \\
\hline
\end{tabular}

Source: Author's Compilation

Diagnostic Tests: The diagnostic tests in Table 7 reveal that the data does not suffer from autocorrelation, heteroscedasticity and specification problems. Further to this, it show that the normally and stability assumptions are supported. Essentially, the diagnostic test results imply consistency of residuals, robustness and adequacy of the model.

Table 7: Diagnostic Test Results

\begin{tabular}{lll}
\hline Tests & & \\
\hline Breusch-Godfrey & F- Statistic (P-Value) & $0.394(0.54)$ \\
Breusch-Pagan-Godfrey & F- Statistic (P-Value) & $1.609(0.17)$ \\
Ramsey RESET Test & F- Statistic (P-Value) & $4.288(0.05)$ \\
Normality Test & Jarque Bera (P-Value) & $1.269(0.53)$ \\
\hline
\end{tabular}

Source: Author's Compilation

Figure 4(a): CUSUM

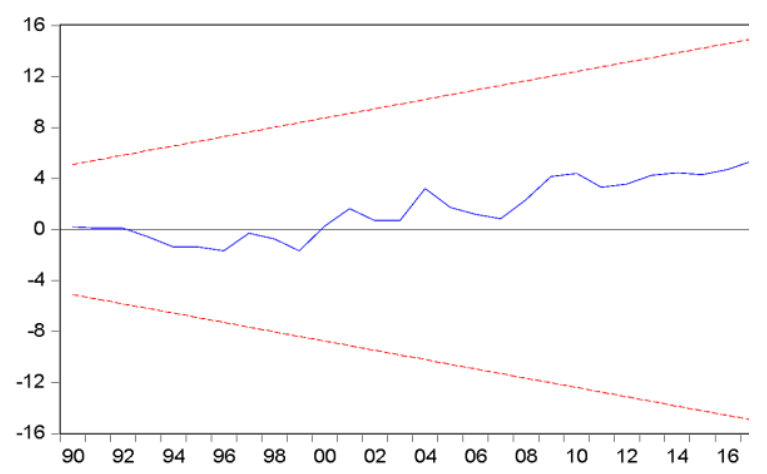

Figure 4(b): CUSUM of Square

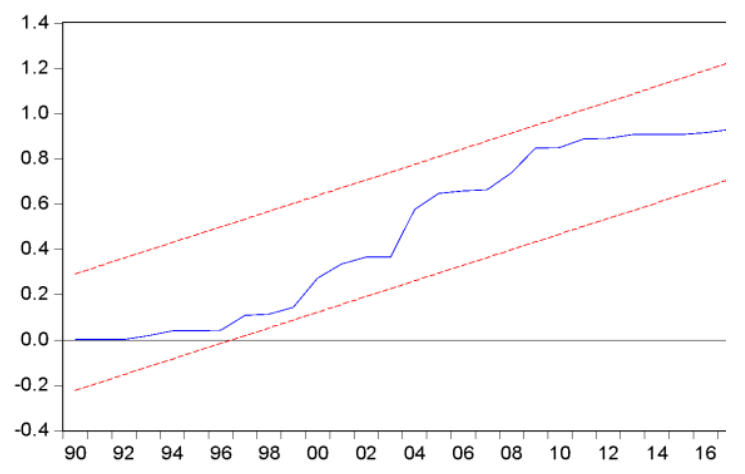

\section{Conclusion and Policy Implications}

This paper examined the effect of government expenditure and money supply on unemployment in Namibia by using an error correction model. There is supporting evidence that cointegration and causality exists. Findings from the short-run model indicate that government expenditure and money supply relate negatively to unemployment and are both statistically significant. This means that a fiscal expansion (rise in government expenditure) will reduce the unemployment rate in Namibia. Similarly, an increase in mon ey supply will lead to a rise in consumption and investment expenditure which ultimately increases the aggregate demand thereby reducing unemployment (Mankiw \& Taylor, 2007). The causality results indicate evidence of a both long and short-run unidirectional causality from government expenditure to unemployment as well as money 
supply to unemployment. A joint causality was also confirmed. Policy implications resulting from the findings of the study are as follows.

Firstly, although the results established that both expansionary monetary and fiscal policy are effective in reducing unemployment in Namibia, the rate of unemployment continues to be high in the country. Therefore, there is need for policy makers to ensure that the goal of employment creation is mainstreamed in all relevant policies and development. Secondly, there is a need to identify and propose policies that can help do away with the lack of effective policy interventions. This is in line with Ka-Fu (2000), who argued that an increase in government expenditure that does not focus toward employment creation may not effectively address unemployment due to disruption by a high level of debt. In addition to this untargeted policy generally leads to deficit spending with minimal or no effect on unemployment. In light of this, the findings imply that effective demand-side policies are crucial to address unemployment in Namibia both in the short and long run. Thirdly, the analysis developed in this study may suffer from some shortcomings. Hence, future research may be considered by using a large sample size and disaggregated data to obtain a more comprehensive conclusion.

\section{References}

Alexius, A. \& Holmlund, B. (2007). Monetary Policy and Swedish Unemployment Fluctuations: Economics Discussion Papers, No 2007-34. Retrieved from Kiel Institute for the World Economy.

Arevuo, M. (2012). Review: Keynes Hayek, The clash that Defined Modern Economics.

Attamah, N., Anthony, I. \& Ukpere, W. I. (2015). The impact of fiscal and monetary policies on unemployment problem in Nigeria. Risk Governance \& Control: Financial Markets Institutions, 5(2), 101-109.

Bank of Namibia. (1991). Annual Report. Windhoek: Bank of Namibia.

Bank of Namibia. (2001). Annual Report. Windhoek: Bank of Namibia.

Bank of Namibia. (2011). Annual Report. Windhoek: Bank of Namibia.

Bank of Namibia. (2016). Annual Report. Windhoek: Bank of Namibia.

Bank of Namibia. (2017). Annual Report. Windhoek: Bank of Namibia.

Byrne, J. P. \& Perman, R. (2007). Unit roots and structural breaks: A survey of the literature In B. B. Rao (ed.), Cointegration for the Applied Economist, (2nd Ed). New York: Palgrave Macmillan.

Dwivedi, D. (2005). Macroeconomics: Theory and Policy. New Delhi: Tata McGraw-Hill Publishing Company Ltd.

Eita, J. H. \& Ashipala, J. M. (2010). Determinants of unemployment. International Journal of Business and Management, 5(10), 92-104.

Etale, L. M. \& Ujuju, L. E. (2016). The Effect of Government Expenditure and Money Supply on Unemployment in Nigeria. International Journal of Management Studies, 3(10), 80-88.

Humphrey, T. (1974). The Quantity Theory of Money: Its Historical Evolution and Role in Policy Debates. Federal Reserve Bank of Richmond Economic Review, 60(3), 2-19.

Jacobs, J. P. A. M., Kuper, G. H. \& Sterken, E. (2003). A structural VAR model of the euro area. CPB Workshop on Economic Policy Modelling, 1-26.

Jelilov, G., Obasa, O. J. \& Isik, A. (2016). The impact of inflation on unemployment in Nigeria (2001-2013). Sacha Journal of Policy and Strategic Studies, 6(1), 28-34.

Ka-Fu, W. (2000). Variability in the effects of monetary policy on economic activity. Journal of Money, Credit, and Banking, 32(2), 179-198.

Li, W. K. (2004). Diagnostic Checks in Time Series. Chapman \& Hall: Boca Raton, FL.

Mankiw, N. G. \& Taylor, M. P. (2007). Macroeconomics. European edition (6th Ed). New York: Worth Publishers.

Ministry of Finance. (2016). Budget Statement. Windhoek: Ministry of Finance.

Mwinga, M. S. (2012). Unemployment in Namibia: Measurement problems, causes and policies. Retrieved from First Capital Working Paper https://www.nmanamibia.com/fileadmin/user_upload/pdf/ Unemployment_in_Namibia_May_2012.pdf

Nakale, S., Sikanda, M. \& Mabuku, M. (2015). Fiscal Policy and the National Economy: Working Paper. 10.13140/RG.2.1.4942.9847. Retrieved from www.npc.gov.na/?wpfb_dl=234 
Namibia Statistic Agency. (2016). The Namibia Labour Force Survey 2016 Report. Windhoek: Namibia Statistics Agency.

Namibia Statistics Agency. (2018). The Namibia Labour Force Survey 2018 Report. Windhoek: Namibia Statistics Agency.

Nwosa, P. I. (2014). Government expenditure, unemployment and poverty rates in Nigeria. Journal of Research in National Development, 12(1), 77-84.

Onodugo, V. A., Obi, K. O., Anowor, O. F., Nwonye, N. G. \& Ofoegbu, G. N. (2017). Does public spending affect unemployment in an emerging market? Risk governance \& control: Financial markets \& institutions, $7(1), 32-40$.

Pesaran, M. H., Shin, Y. \& Smith, R. J. (2001). Bounds testing approaches to the analysis of level relationships. Journal of applied econometrics, 16(3), 289-326.

Sanz-Bas, D. (2011). Hayek's Critique of the General Theory: A New View of the Debate between Hayek and Keynes. The Quarterly Journal of Austrian Economics, 14(3), 288-310.

Schiller, R. B. (2016). The Economy Today (10th ed). New York: McGraw-Hill.

Sebuliba, N. (2017). Monetary and Fiscal Policy Effects on Unemployment and Inflation in Uganda. Nelson Mandela Metropolitan University.

Shifotoka, H. (2015). Investigating the relationship between bank rate, unemployment and inflation: The Phillips curve in Namibia. Retrieved from University of Namibia: http://repository.unam.na/ bitstream/handle/11070/1679/Shifotoka_2015.pdf?sequence=1\&isAllowed=y

Sodipo, O. A. \& Ogunrinola, O. I. (2011). Employment and Economic Growth Nexus in Nigeria. International Journal of Business and Social Science, 2(1), 232-239.

Sunde, T. \& Akanbi, O. A. (2016). Sources of unemployment in Namibia: an application of the structural VAR approach. International Journal of Sustainable Economy, 8(2), 125-143.

Sunde, T. (2015). The effects of monetary policy on unemployment in Namibia. Journal of Economic and Social Thought, 2(4), 256-274.

Tagkalakis, A. (2013). The unemployment effects of fiscal policy: recent evidence from Greece. IZA Journal of European Labour Studies, 2(1), 1-32.

Wickens, M. (2008). Macroeconomic Theory. A Dynamic General Equilibrium Approach. New Jersey: Princeton. 